\title{
Potentials and Safety of Date Palm Fruit against Diabetes: A Critical Review
}

\author{
Md Al-Tareq Mia ${ }^{1}$, Md Golam Mosaib ${ }^{2}$, Md Ibrahim Khalil ${ }^{1}$, Md Asiful Islam ${ }^{3, *(1)}$ \\ and Siew Hua Gan $4, * \mathbb{D}$ \\ 1 Laboratory of Preventive and Integrative Biomedicine, Department of Biochemistry and Molecular Biology, \\ Jahangirnagar University, Savar, Dhaka 1342, Bangladesh; tareqmia454@gmail.com (M.A.-T.M.); \\ drmikhalil@gmail.com (M.I.K.) \\ 2 Department of Biochemistry and Molecular Biology, Gono University, Savar, Dhaka 1344, Bangladesh; \\ gmosaib@gmail.com \\ 3 Department of Haematology, School of Medical Sciences, Universiti Sains Malaysia, \\ Kubang Kerian 16150, Kelantan, Malaysia \\ 4 School of Pharmacy, Monash University Malaysia, Jalan Lagoon Selatan, \\ Bandar Sunway 47500, Selangor, Malaysia \\ * Correspondence: asiful@usm.my or ayoncx70@yahoo.com (M.A.I.); gan.siewhua@monash.edu (S.H.G.)
}

Received: 3 August 2020; Accepted: 27 October 2020; Published: 28 October 2020

\begin{abstract}
Diabetes is a chronic metabolic disorder triggered by disturbances in carbohydrate, protein, and lipid metabolisms, where either reduced secretion or sensitivity of insulin is observed coupled with poor glucose control. Date palm fruits are one of the fruits reported to have good potential in diabetes treatment due to its presence of polyphenols exerting strong antioxidant activities. Other possible mechanisms of action include the polyphenolic compounds, which can inhibit enzymes like $\alpha$-amylase and $\alpha$-glucosidase. Flavonoids in dates can stimulate $\beta$-cells by increasing the number of islets and $\beta$-cells, recovering endocrine pancreatic tissues, reducing $\beta$-cell apoptosis, activating insulin receptors following the increase in insulin secretion, in addition to improving diabetes-induced complications. In this review, the in vitro, in vivo, and human study-based evidence of date palm as an anti-diabetic fruit is summarised.
\end{abstract}

Keywords: date palm; Phoenix dactylifera; dates; polyphenols; flavonoids; diabetes; anti-diabetic

\section{Introduction}

Diabetes mellitus (DM) is a disease that is universally emerging, incurring long-standing complexities on organs, including the heart, kidneys, retina, and peripheral nerves. Natural products, which are often free from side effects, are good alternatives for disease amelioration [1-3]. Additionally, natural products have potentially effective roles in regulating diabetes and its complications $[2,4,5]$.

Date palm fruit (Phoenix dactylifera) is from the Arecaceae or Palmae family. It is one of the oldest cultivated plants and originates from the Arabian Peninsula. There are more than 2000 distinct assortments of dates, including Ajwa, Khalas, Ruthana, Sukkary, Sefri, Segae, Khodry, Lulu, Hilali, and Munifi $[6,7]$. Dates are very nutritious and are rich in starch, salts, minerals, nutrients, unsaturated fats, proteins and fibres [8,9].

The presence of variable active constituents in dates including flavonoids, steroids, phenol, and saponins are postulated to exert anti-diabetic activities mainly by scavenging the free radicals via antioxidant activities and by inhibiting $\alpha$-amylase and $\alpha$-glucosidase enzymes [10-13]. Fibres and fructose are glucose-lowering, where consumption of dates up to $76.2 \mathrm{~g}$ as a snack is purported to be beneficial in Arabic culinary tradition, and can maintain the postprandial glucose levels in 
patients with diabetes $[14,15]$. Additionally, the date palm has numerous therapeutic potentials, including cell reinforcement, anti-mutagenic, antibacterial, antifungal, antitumor, neuroprotective, and gastroprotective properties [16,17]. The antioxidant potential in dates is perceived to be contributed by the wide range of phenolic components present, including $p$-coumaric, flavonoids, procyanidins, ferulic, and sinapic acids. Other investigations indicated that the date palm possesses thirteen flavonoid glycosides, including luteolin, quercetin, and apigenin. Ajwa date, also known as a "super date", and found only in Saudi Arabia, has good nutritional and medicinal values, making it one of the most expensive date varieties [18-20].

Although, to date, only a single study systematically reviewed the potentials of date seeds exerting anti-diabetic activity [21], there is no such review to critically assess the potentials and safety of date palm fruit on diabetes. Therefore, the objective of this comprehensive review is to summarise the potential anti-diabetic activities and safety of date palm fruits based on the in vitro, in vivo, as well as human experimental studies.

\section{Materials and Methods}

Different databases, including PubMed, Scopus, and Google Scholar, were searched using the following keywords: Phoenix dactylifera, dates, date palm, palm date, date fruit, date fruits, date seed, date seeds, diabetes, diabetic, prediabetic, hyperglycemic, hypoglycemic, hyperglycaemic, and hypoglycaemic. There was no limit in the year of publication and studies published in English were only considered. The final search was conducted on 20 July 2020.

\section{Physicochemical and Nutritional Composition}

Many studies confirmed that date palm fruit is rich in carbohydrates (glucose: $42.3-51.8 \%$, fructose: $22.5-47.5 \%$, sucrose: $3.2-7.4 \%)$, proteins $(1.8-3.0 \%)$, and fibre $(2.2 \%)$ [22,23]. Date palm seeds were detected with high levels of fatty acids, such as oleic $(36.6-50.1 \%)$, linoleic $(8.9-19.2 \%)$, lauric (10.2-20.4\%), palmitic (9.8-10.2\%), and stearic acids (7.5-10.7\%), in addition to some essential oils and major tocols, including $\alpha-, \beta-$, and $\gamma$-tocotrienols [22,24-26]. Minerals, such as potassium, calcium, and magnesium were also detected in date palms $[23,24]$. Date fruits also contain various types of polyphenols and flavonoids, which are believed to be potential sources of bioactive compounds offering health benefits (Table 1). 
Table 1. Polyphenols extracted from date fruits.

\begin{tabular}{|c|c|c|c|c|}
\hline No. & Types of Date & Polyphenols & Country & References \\
\hline 1 & $\begin{array}{l}\text { Deglet Nour and Ftimi } \\
\text { (Phoenix dactylifera L.) }\end{array}$ & $\begin{array}{ll}\text { - } & \text { Caffeoylshikimic acid hexoside } \\
\text { - } & \text { 4-Caffeoylshikimic acid } \\
\text { - } & \text { 5-Caffeoylshikimic acid } \\
\text { - } & \text { 3-Caffeoylshikimic acid } \\
\text { - } & \text { Caffeoylshikimic acid hexoside } \\
\text { - } & \text { Caffeoyl-sinapoyl hexoside } \\
\text { - } & \text { Dicaffeoyl-sinapoyl hexoside } \\
\end{array}$ & Tunisia & [27] \\
\hline 2 & $\begin{array}{c}\text { Date palm } \\
\text { (Phoenix dactylifera } \mathrm{L} .)\end{array}$ & $\begin{array}{ll}\text { - } & \text { Ellagic acid } \\
\text { - } & \text { Gallic acid } \\
\text { - } & \text { p-Coumaric acid } \\
\end{array}$ & Tunisia & [28] \\
\hline 3 & $\begin{array}{l}\text { Date palm pollen } \\
\text { (Phoenix dactylifera L.) }\end{array}$ & $\begin{array}{ll}\text { - } & \text { Luteolin-7-O- } \beta \text {-D-glucoside } \\
\text { - } & \text { Apigenin } \\
\text { - } & \text { Isorhamnetin-3-O-glucoside } \\
\text { - } & \text { Naringin }\end{array}$ & Egypt & [29] \\
\hline 4 & $\begin{array}{c}\text { Date palm } \\
\text { (Phoenix dactylifera L.) }\end{array}$ & - $\quad$ Gallic acid & Oman & [30] \\
\hline 5 & $\begin{array}{l}\text { Fardh, Khasab, and Khalas date fruits } \\
\text { (Phoenix dactylifera L.) }\end{array}$ & - Catechin & Oman & [31] \\
\hline 6 & $\begin{array}{l}\text { Date palm Ajwa, Barni } \\
\text { (Phoenix dactylifera L.) }\end{array}$ & $\begin{array}{ll}\text { - } & \text { Hydroxybenzoic acid } \\
\text { - } & \text { Hydroxycinnamic acid } \\
\end{array}$ & United Kingdom & [32] \\
\hline 7 & $\begin{array}{c}\text { Date palm } \\
\text { (Phoenix dactylifera } \mathrm{L} .)\end{array}$ & $\begin{array}{ll}\text { - } & \text { Ferulic acid } \\
\text { - } & \text { Sinapic acid }\end{array}$ & Morocco & [33] \\
\hline 8 & $\begin{array}{c}\text { Date palm } \\
\text { (Phoenix dactylifera L.) }\end{array}$ & $\begin{array}{ll}\text { - } & \text { Caffeic acid } \\
\text { - } & \text { Epicatechin } \\
\text { - } & \text { Vanillic acid } \\
\text { - } & \text { Coumarin } \\
\text { - } & \text { Quercetin } \\
\text { - } & \text { Rutin }\end{array}$ & Tunisia & [34] \\
\hline
\end{tabular}


Table 1. Cont.

\begin{tabular}{|c|c|c|c|c|}
\hline No. & Types of Date & Polyphenols & Country & References \\
\hline 9 & Harvest date & $\begin{array}{ll}\text { - } & \text { Rutin } \\
\text { - } & \text { Quercitrin } \\
\text { - } & \text { Lisetin } \\
\text { - } & \text { Myricetin } \\
\text { - } & \text { Morin } \\
\text { - } & \text { Luteolin } \\
\text { - } & \text { Quercetin } \\
\text { - } & \text { Apigenin, } \\
\text { - } & \text { Kaempferol } \\
\text { - } & \text { Isorhamnetin } \\
\text { - } & \text { Rhamnetin } \\
\text { - } & \text { Galangin }\end{array}$ & China & [35] \\
\hline 10 & $\begin{array}{c}\text { Date palm } \\
\text { (Phoenix dactylifera L.) }\end{array}$ & $\begin{array}{ll}\text { - } & \text { Diosmetin 7-O-L-arabinofuranosyl-D-apiofuranoside } \\
\text { - } & \text { Diosmetin 7-O-D-apiofuranoside }\end{array}$ & Egypt & [36] \\
\hline 11 & $\begin{array}{c}\text { Palm Date } \\
\text { (Phoenix dactylifera L.) }\end{array}$ & $\begin{array}{ll}\text { - } & \text { Gallic acid } \\
\text { - } & \text { Caffeic acid } \\
\text { - } & \text { p-Coumaric acid } \\
\text { - } & \text { Quercetin } \\
\text { - } & \text { Ferulic acid } \\
\text { - } & \text { Chlorogenic acid } \\
\text { - } & \text { Luteolin-7-O-rutinoside } \\
\text { - } & \text { Apigenin-c-glycoside } \\
\text { - } & \text { Quercetin3-O-rutinoside } \\
\text { - } & \text { Protocatechuic acid } \\
\text { - } & \text { Vanillic acid } \\
\text { - } & \text { m-Coumaric acid } \\
\text { - } & \text { o-Coumaric acid } \\
\text { - } & \text { 5-o-Caffeoyl shikimic acid } \\
\text { Cinnamic acid }\end{array}$ & Egypt & [37] \\
\hline
\end{tabular}


Table 1. Cont.

\begin{tabular}{|c|c|c|c|c|}
\hline No. & Types of Date & Polyphenols & Country & References \\
\hline 12 & $\begin{array}{c}\text { Desert date } \\
\text { (Balanites aegyptiaca) }\end{array}$ & $\begin{array}{ll}\text { - } & \text { Vanillic acid } \\
\text { - } & \text { Syringic acid } \\
\text { - } & \beta \text {-sitosterol } \\
\end{array}$ & Saudi Arabia & [38] \\
\hline 13 & $\begin{array}{c}\text { Desert date } \\
\text { (Balanites aegyptiaca) }\end{array}$ & $\begin{array}{ll}\text { - } & \text { Epicatechin-O-glucoside } \\
\text { - } & \text { Rutin } \\
\text { - } & \text { Isorhamnetin-3-O-rutinoside } \\
\text { - } & \text { Isorhamnetin-3-O-glucoside } \\
\text { - } & \text { Quercetin } \\
\text { - } & \text { Isorhamnetin }\end{array}$ & Egypt & [11] \\
\hline 14 & $\begin{array}{c}\text { Date palm } \\
\text { (Phoenix dactylifera L.) }\end{array}$ & $\begin{array}{ll}\text { - } & \text { Salicylic acid } \\
\text { - } & \text { kaempferol-3-glucoside } \\
\text { - } & \text { p-Hydroxybenzoic acid } \\
\text { - } & \text { Protocatechuic acid } \\
\text { - } & \text { Vanillic acid } \\
\text { - } & \text { Gallic acid } \\
\text { - } & \text { Syringic acid } \\
\text { - } & \text { o-Coumaric acid } \\
\text { - } & \text { Caffeic acid } \\
\text { - } & \text { Ferulic acid } \\
\text { - } & \text { Xanthoxylin acid } \\
\text { - } & \text { Hydrocaffeic acid } \\
& \text { Coumaroylquinic acid Protocatechuic acid } \\
\end{array}$ & Oman & [39] \\
\hline 15 & $\begin{array}{c}\text { Date Palm } \\
\text { (Phoenix dactylifera L.) }\end{array}$ & $\begin{array}{ll}\text { - } & \text { Gallic acid } \\
\text { - } & \text { p-Hydroxybenzoic acid } \\
\text { - } & \text { Vanillic acid } \\
\text { - } & \text { p-Coumaric acid } \\
\text { - } & \text { Protocatechuic acid } \\
\text { - } & \text { Syringic acid } \\
\text { - } & \text { Caffeic acid } \\
\text { - } & \text { Ferulic acid }\end{array}$ & Tunisia & [40] \\
\hline
\end{tabular}


Table 1. Cont

\begin{tabular}{|c|c|c|c|c|}
\hline No. & Types of Date & Polyphenols & Country & References \\
\hline 16 & Date syrup & $\begin{array}{ll}\text { - } & \text { Quercetin } \\
\text { - } & \text { Epigallocatechin } \\
\text { - } & \text { Gallate } \\
\text { - } & \text { Curcumin } \\
\text { - } & \text { Resveratrol }\end{array}$ & United Kingdom & [41] \\
\hline 17 & $\begin{array}{c}\text { Date palm } \\
\text { (Phoenix dactylifera L.) }\end{array}$ & $\begin{array}{ll}\text { - } & \text { Isoquercitrin } \\
\text { - } & \text { Luteolin 7-O- } \beta \text {-D-neohesperopyranoside } \\
\text { - } & \text { 3j-O-methylether } \\
\text { - } & \text { Luteolin 7-O- } \beta \text {-D-neohesperopyranoside } \\
\text { - } & \text { Acacetin 7-O- } \beta \text {-D-neohesperopyranoside } \\
\text { - } & \text { Apigenin 7-O-D-apiofuranoside } \\
\text { - } & \text { Genistein } 8-C-D-\beta-D \text {-D glucopyranoside }\end{array}$ & Egypt & [42] \\
\hline 18 & $\begin{array}{l}\text { Barhee and Zahdi dates } \\
\text { (Phoenix dactylifera L.) }\end{array}$ & $\begin{array}{ll}\text { - } & \text { Catechol } \\
\text { - } & 4 \text { methyl catechol } \\
\text { - } & \text { Chlorogenic acid } \\
\text { - } & \text { Caffeic acid }\end{array}$ & Iraq & [43] \\
\hline 19 & $\begin{array}{c}\text { Deglet Nour } \\
\text { (Phoenix dactylifera L.) }\end{array}$ & $\begin{array}{ll}\text { - } & \text { Procyanidin } \\
\text { - } & \text { Protocatechuic acid } \\
\text { - } & \text { Epicatechin } \\
\text { - } & \text { Caffeoylshikimic acid } \\
\text { - } & \text { Apigenin di-C-hexoside } \\
\text { - } & \text { Hydroxycinnamic acid } \\
\text { - } & \text { Kaercetin } \\
\end{array}$ & Australia & [44] \\
\hline 20 & $\begin{array}{c}\text { Date palm } \\
\text { (Phoenix dactylifera L.) }\end{array}$ & $\begin{array}{ll}\text { - } & \text { Catechin } \\
\text { - } & \text { Epicatechin } \\
\text { - } & \text { Procyanidin B1 } \\
\text { - } & \text { Procyanidin B2 } \\
\text { - } & \text { Procyanidin A2 }\end{array}$ & Australia & [45] \\
\hline
\end{tabular}




\section{Date Fruit Flesh}

\subsection{Evidence from In Vivo Studies}

\subsubsection{Antihyperglycemic Activity}

Phoenix dactylifera extracts were administered to streptozotocin-induced type 2 diabetes mellitus (T2DM) rats $(n=50)$ daily for a month, and were found to significantly decrease $(p<0.001)$ glucose levels and increase insulin concentration [46]. Balanites aegyptiaca (Heglig dates) reduced blood glucose $(209.4 \pm 48.2 \mathrm{mg} / \mathrm{dL}$ vs. $410.2 \pm 45.6 \mathrm{mg} / \mathrm{dL})$ and haemoglobin A1c (HbA1c) levels $(8.1 \pm 1.4 \mathrm{vs}$ $6.7 \pm 1.5)$ and improved insulin secretion $(1.2 \pm 0.3$ vs. $1.9 \pm 0.3)$ as compared to the untreated diabetic group [47]. The possible mechanism was through flavonoids, which can increase the number of $\beta$-cells and stimulate insulin secretion (Figure 1) [48]. In another 14-day in vivo study [49], Phoenix dactylifera fruit pulps were administered to diabetic rats and the dates were found to significantly $(p<0.05)$ reduce blood glucose levels as compared to that for the control and diabetic untreated groups. The possible mechanism is believed to be due to the slowing of gastric emptying by the action of polyphenols found in date fruits (Table 1) [50]. The findings indicate that date fruit pulp has the potential to be used for glucose-lowering. Subsequently, El Abed et al. [10] confirmed that date fruit extract significantly $(p<0.01)$ reduced the plasma glucose level (from 214.0 to $157.2 \mathrm{mg} / \mathrm{dL}$ ) as compared to acarbose in diabetic albino mice.

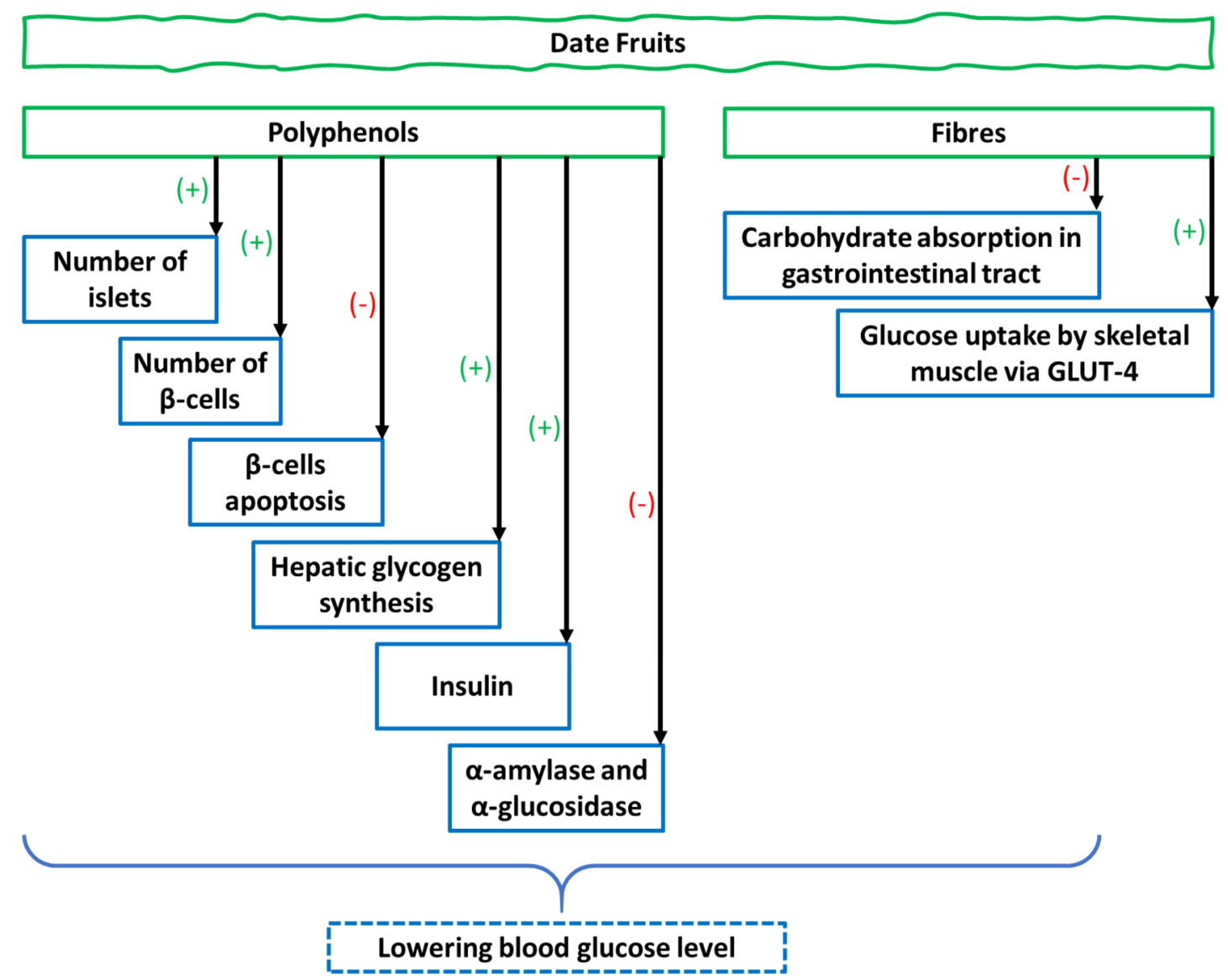

Figure 1. Mechanism of action of polyphenols and fibres of date fruits in ameliorating diabetes.

In another study, Aseel or the native variety was orally administered to 32 normoglycaemic and hyperglycaemic Sprague-Dawley rats in two doses (300 and $600 \mathrm{mg} / \mathrm{kg}$ ). At the end of the experiment, there was insignificant blood glucose reduction in normoglycaemic rats, although these changes were 
significant $(p<0.005)$ in hyperglycaemic rats (from $281.4 \pm 8.0$ to $203.2 \pm 12.0 \mathrm{mg} / \mathrm{dL}$ ) [51]. It is plausible that dietary fibres from the date extract reduce carbohydrate absorption in the gastrointestinal tract and affect glucose uptake by skeletal muscle insulin responsive glucose transporter (GLUT)-4 [48]. Additionally, polyphenolic compounds of date extract may have the capacity to inhibit $\alpha$-amylase and $\alpha$-glucosidase, which are involved in carbohydrate breakdown, as well as intestinal absorption (Figure 1) [52]. In a 36-day in vivo study on male Sprague-Dawley rats, the animals were divided into three groups (normal, insulin-treated, and insulin-untreated) followed by the oral administration of either $0 \%$ or $10 \%$ Birhi tamr date variety for six weeks. Ibrahim et al. [53] observed no significant difference in blood glucose levels between normal or insulin-treated rats, although there was significant increase $(p<0.05)$ in insulin-untreated rats; $(496.0 \pm 81.6$ and $315.0 \pm 61.1 \mathrm{mg} / \mathrm{dL}$, respectively) compared to normal $(147.0 \pm 5.3$ and $156.0 \pm 7.6 \mathrm{mg} / \mathrm{dL}$, respectively) and insulin-treated diabetic rats $(227.0 \pm 17.6$ and $268.0 \pm 18.9 \mathrm{mg} / \mathrm{dL}$, respectively) for $0 \%$ and $10 \%$ Birhi tamr administration. The findings indicate that Birhi tamr date fruit is beneficial for diabetic patients. Interestingly, the authors hypothesized that the antihyperglycemic activity seen was contributed by the presence of insulin-like substance in the Birhi tamr date fruit.

The efficacy of desert dates (Balanites aegyptiaca) was evaluated in a 28-day in vivo study, where it was found to significantly $(p<0.001)$ reduce blood glucose levels and body weight in addition to improve insulin secretion, MDA, and liver-pyruvate kinase levels, the size of pancreas, and the islets of Langerhans $(p<0.001)$ [54]. It is plausible that genistein, a flavonoid found in dates reduces $\beta$-cells apoptosis, increases $\beta$-cells number, promotes $\beta$-cells survival in pancreatic islets and preserves islets mass, subsequently increasing insulin secretion while reducing glucose levels due to activated liver-pyruvate kinase [55]. In another six-week in vivo study, Bendary et al. [56] evaluated glucose, insulin and $\mathrm{HbA} 1 \mathrm{c}$ levels in albino rats $(n=40)$. At the end of experiment, they found that serum glucose, insulin and $\mathrm{HbA} 1 \mathrm{c}$ levels were $133.2 \pm 7.2 \mathrm{mg} / \mathrm{dL}, 9.0 \pm 0.2 \mu / \mathrm{mL}$ and $0.53 \pm 0.02 \mathrm{mg} / \mathrm{g} \mathrm{Hb}$, respectively for date fruit extract-treated group as compared to $299.6 \pm 16.7 \mathrm{mg} / \mathrm{dL}, 8.9 \pm 0.7 \mu \mathrm{U} / \mathrm{mL}$ and $0.9 \pm 0.05 \mathrm{mg} / \mathrm{g} \mathrm{Hb}$ for untreated group $(p<0.05)$. Glucose metabolism was improved possibly due to the action of polyphenols such as flavonoids, anthocyanins and phenolic acids, which can detoxify free radicals and inhibit lipid peroxidation [57].

In an eight-week in vivo study by Al-Malki et al. [38], ethyl acetate extracts of Balanites aegyptiaca date were administered to diabetic rats. It was observed that the extracts significantly reduced glucose levels as compared to untreated diabetic rats $(340.0 \pm 15.8$ vs. $280.0 \pm 13.0 ; p<0.05)$. It also significantly reduced $\mathrm{HbA} 1 \mathrm{c}$ levels in treated diabetic rats compared to untreated diabetic rats $(7.4 \pm 0.8$ vs. $6.6 \pm 0.6$; $p<0.05)$. In addition, vascular endothelial growth factor levels were significantly reduced in diabetic retina $(p<0.001)$, suggesting that date fruit may provide additional endothelial protection to the retina. In a separate study, alloxan-induced male Wister diabetic rats $(n=30)$ were experimented in a 10-day trial involving the administration of date fruits. A significant decrease in glucose level was observed in treated rats $(p<0.05)$ compared to untreated diabetic rats [58]. Two natural flavonoid compounds (diosmetin 7-O- $\beta$-L-arabinofuranosyl $\beta$-D-apiofuranoside and diosmetin 7-O- $\beta$-D-apiofuranoside) were isolated from date fruits and were administered in a group of male diabetic rats. Interestingly, Michael et al. [36] identified that the compounds were able to significantly $(p<0.01)$ reduce blood glucose levels from $330.0 \pm 5.5$ to $140.0 \pm 1.2$ and $158.0 \pm 1.3 \mathrm{mg} / \mathrm{dL}$, respectively indicating that both compounds have potentials in lowering blood glucose level.

\subsubsection{Antihyperglycemic Activity}

In an in vivo study [58], it was observed that the effects of date palm fruit on lipid profile where significant, especially on cholesterol, low-density lipoprotein (LDL), and triacylglyceride (TG) in diabetic rats compared to that in untreated diabetic rats; however, no significant change in high-density lipoprotein (HDL) levels. 


\subsubsection{Against Diabetes-Induced Testicular Toxicity}

In an interesting eight-week study, Hosseinipour et al. [59] evaluated the alcoholic extract of Asrasi date on diabetes-induced testicular injuries on streptozotocin-induced male T2DM rats $(n=40)$. The levels of testis superoxide dismutase (SOD), glutathione peroxidase (GPx), catalase (CAT), and malondialdehyde (MDA) were ameliorated in diabetic rats in addition of recovering serum testosterone levels and $B C L-2$ expression. Therefore, it is evident that Asrasi date extract with potential antioxidant effects can improve diabetes-induced oxidative stress and structural changes in the testis by strengthening the testicular antioxidant defence system.

\subsubsection{Against Diabetes-Induced Cardiomyopathy}

In a remarkable in vivo study, Saddi et al. [46] observed that following the administration of Phoenix dactylifera extracts, the serum inflammatory molecules, tumour necrosis factor (TNF- $\alpha$ ) and C-reactive protein were improved, besides scaling down the serum cardiac function enzyme: creatine phosphokinase-MB in diabetic rats compared to untreated diabetic rats. Additionally, increased levels of cardiac antioxidant enzymes including MDA, GPx were detected with attenuated the cardiac apoptosis enzyme: caspase-3 and the oxidative DNA fragmentation. Altogether, Phoenix dactylifera extracts were confirmed to possess pleiotropic protective mechanisms against diabetic cardiomyopathy including anti-diabetic, anti-inflammatory, antioxidant, and anti-apoptosis activities.

\subsubsection{Ameliorating Haematological Parameters}

Zaakouk et al. [47] in his in vivo study concluded that date consumption can improve red blood cells (RBCs), white blood cells and haemoglobin $(\mathrm{Hb})$ levels in diabetic rats compared to untreated diabetic rats, indicating that dates can restore diabetes-induced anaemic condition. Another in vivo study [49] also supports the fact that Phoenix dactylifera fruit extracts has the potential to significantly improve $(p<0.05)$ the $\mathrm{RBCs}$ and $\mathrm{Hb}$ level in diabetic rats.

\subsubsection{Neuroprotective Activity}

In a six-week experiment on streptozotocin-induced diabetic rats, date fruit extract conferred significant improvement in diabetic neuropathy as compared to the control group [60]. In diabetic rats, oxidative stress causes reduction in vascular impairment as a result of endoneurial hypoxia, thus, contributing to impairment in neuronal function. Nevertheless, cinnamic acid, flavonoids, and vitamin $\mathrm{C}$ of date fruit extract can ameliorate the damages via their antioxidant and free radical scavenger activities. As a result, there is inhibition of the production of reactive oxygen species, which help to prevent oxidative stress and stimulate Schwann cells to produce nerve growth factors, helpful for neuronal support [61]. Similarly, Bendary et al. [56] also observed neuroprotective activities of date palm fruit, although the mechanism was unclear.

Taken together, the findings from the animal studies indicated that date consumption not only contributes to improvement in plasma glucose, $\mathrm{HbA} 1 \mathrm{c}$ levels and insulin secretion, but also contributes to the protection of neurons, haematological biomarkers, cardiomyopathy, testicular toxicity, and improved pancreas along with retinal structure in animal models of T2DM.

\subsection{Evidence from Clinical Studies}

\subsubsection{Antihyperglycemic Activity}

In the last 20 years, a few studies on date consumption in T2DM patients have been conducted (Table 2). In a randomised controlled trial [62], T2DM patients $(n=55)$ having blood glucose levels of more than $126 \mathrm{mg} / \mathrm{dL}$ were treated with date vinegar $(20 \mathrm{~mL})$ together with their normal diet for 7 weeks. Subsequently, it was observed that date vinegar significantly $(p=0.001)$ ameliorated the levels of HbA1c $(6.8 \pm 2.3$ to $6.1 \pm 2.1(\%))$ and fasting blood sugar $(171.4 \pm 36.7$ to $147.5 \pm 38.8 \mathrm{mg} / \mathrm{dL})$ indicating 
that date vinegar may be useful for diabetics. Acetic acid, which is the major component of date vinegar, may stall digestion of starch molecules in the small intestine by blocking disaccharide activity and reduce glucose uptake via muscle performance; it also responsible for gastric emptying. Additionally, fructose and dietary fibres may also be responsible for reducing blood glucose levels [63,64]. However, as this study was not on natural date fruit, the results should be used with caution in compared to those studies on natural date palm fruits. In order to identify the relationship between date fruit consumption and prevalence of developing T2DM, a large study on diabetic and non-diabetic Saudi patients $(n=2177)$ were conducted. This experiment revealed that there was no significant relationship between date consumption and the prevalence of developing T2DM. On the other hand, positive effects were observed since the dates provide dietary fibres and non-starch polysaccharides [65]. In another interesting study [66], hot water and sun drying treatments were utilised to reduce date sugar content. Both treatments could significantly reduce the sugar (fructose, glucose and inverted sugar) and mineral content (sodium, potassium, and calcium), making dates more suitable for diabetics. In a crossover clinical trial, Bam Mazafati dates and raisins were administered to patients with T2DM $(n=15)$ as a snack. After $2 \mathrm{~h}$ of snack (24.2 g or approximately 2 dates), it was noted that the dates did not significantly increase blood glucose levels (125.0 \pm 18.9 (fasting), $161.2 \pm 46.9$ ( $2 \mathrm{~h}$ after breakfast) and $103.8 \pm 20.9 \mathrm{mg} / \mathrm{dL}$ ( $2 \mathrm{~h}$ after date snack)) possibly due to the presence of the high polyphenol content [67]. Therefore, for diabetic patients, dates can be a nutrient-based beneficial snack as compared to sugar-based snacks [68]. 
Table 2. Date consumption studies in human T2DM subjects.

\begin{tabular}{|c|c|c|c|c|c|c|}
\hline $\begin{array}{c}\text { Study ID } \\
\text { [References] }\end{array}$ & Country & Study Design & $\begin{array}{c}\text { Number of } \\
\text { Participants (Female) }\end{array}$ & Date Consumption & Study Duration & Outcomes \\
\hline Al-Mssallem 2018 [65] & Saudi Arabia & Cross-sectional & $2177(1133)$ & 100 g/day & $\begin{array}{l}\text { Weekly and monthly } \\
\text { consumption of dates } \\
\text { was recorded }\end{array}$ & $\begin{array}{l}\text { Consumption of dates has no association } \\
\text { with the prevalence of T2DM }\end{array}$ \\
\hline Ali 2018 [62] & Pakistan & $\begin{array}{l}\text { Double-blinded } \\
\text { randomised-controlled trial }\end{array}$ & $60(29)$ & $20 \mathrm{~mL} /$ day & 10 weeks & $\begin{array}{c}\text { Date vinegar improved blood } \\
\text { concentrations of HbA1c and FBS } \\
(p<0.05) \text { in patients with T2DM }\end{array}$ \\
\hline Foshati 2015 [68] & Iran & $\begin{array}{c}\text { Non-randomised crossover } \\
\text { clinical trial }\end{array}$ & $15(10)$ & $24.2 \mathrm{~g}$ & 3 days & $\begin{array}{l}\text { Consumption of dates did not increase } \\
\text { blood glucose }\end{array}$ \\
\hline Alkaabi 2013 [69] & $\begin{array}{l}\text { United Arab } \\
\text { Emirates }\end{array}$ & Case-control & $10(5)$ & $50 \mathrm{~g}$ & 5 days & $\begin{array}{l}\text { Dates exhibited as a low-GI fruit for } \\
\text { patients with T2DM when consumed } \\
\text { with and without Arabic coffee }\end{array}$ \\
\hline Alkaabi 2011 [15] & $\begin{array}{l}\text { United Arab } \\
\text { Emirates }\end{array}$ & Non-randomised clinical trial & 10 & $50 \mathrm{~g}$ & 3 days & $\begin{array}{l}\text { Diabetic individuals do not result in } \\
\text { significant postprandial glucose } \\
\text { excursions due to the date consumption }\end{array}$ \\
\hline Forghani 2003 [70] & Iran & Non-randomised clinical trial & 16 & NR & 2 days & $\begin{array}{l}\text { Glucose level decreases substantially } \\
\text { following replacing the bread content in } \\
\text { a diabetic diet with dates }\end{array}$ \\
\hline
\end{tabular}

T2DM: type 2 diabetes mellitus; HbA1c: glycated haemoglobin; FBS: fasting blood sugar; GI: glycaemic index; NR: not reported. 
Alkaabi et al. [69] evaluated the effects of traditional Arabic coffee consumption with Khalas date on glycaemic index in diabetic $(n=10)$ and healthy subjects $(n=13)$. Following a short-term (five days) experiment, there was no significant increase in the glycaemic index in the healthy individuals $(52.7 \pm 6.2 \mathrm{mg} / \mathrm{dL})$ or in diabetic patients $(41.5 \pm 5.4 \mathrm{mg} / \mathrm{dL})$. This phenomenon occurred possibly because of the presence of caffeine, which stimulates the secretion of epinephrine, which have an opposite action to insulin by acting via $\beta$-adrenergic stimulation [71]. Therefore, it was postulated that consumption of Arabic coffee along with Khalas dates can reduce blood glucose levels although a longer duration study is required to further confirm the findings. In another study [15], five varieties of dates (Fara'd, Lulu, Bo ma'an, Dabbas, and Khalas) were evaluated in diabetic and healthy individuals for eight days, by using $50 \mathrm{~g}$ of date flesh. There was no significant difference in the mean glycaemic indices of healthy and diabetic patients where the healthy individuals had $54.0 \pm 6.1,53.5 \pm 8.6$, $46.3 \pm 7.1,49.1 \pm 3.6,55.1 \pm 7.7$ while the diabetics had $46.1 \pm 6.2,43.8 \pm 7.7,51.8 \pm 6.9,50.2 \pm 3.9$, and $53.0 \pm 6.0$ for Fara'd, Lulu, Bo ma'an, Dabbas, and Khalas dates, respectively. The finding indicates that the date varieties do not increase the glycaemic indices in healthy or diabetic individuals.

The effect of dates which contained $25 \%$ fructose were evaluated in a clinical study with T2DM individuals $(n=16)$. Dates can decrease blood glucose levels when they were replaced with equal amount of bread in the breakfast $(117.0 \pm 21.6 \mathrm{mg} / \mathrm{dL}$ vs. $148.0 \pm 32.4 \mathrm{mg} / \mathrm{dL} ; p=0.02$ [70] possibly due to the rich presence of polyphenols and dietary fibres. Ahmed et al. [72] evaluated the glycaemic index in Saudi individuals $(n=19)$ who had Arabian breakfast like organic juice, boiled egg, hot milk, Arabic coffee, Arabic bread, and a date meal. It was noted that Khalas date meal was significantly better in terms of maintaining glycaemic index $(57.7 \mathrm{mg} / \mathrm{dL} v \mathrm{vs} .79 .0 \mathrm{mg} / \mathrm{dL})$ because it contains fructose as well as fibres [73]. Therefore, the study concluded that date meal is a beneficial diet for diabetic subjects as compared to conventional Saudi breakfast.

In a comparative clinical trial of type $1 \mathrm{DM}$ patients $(n=20)$, a date $(10 \mathrm{~g})$ and a sugar cube $(5 \mathrm{~g})$ were administered to two groups of patients. Subsequently, their blood glucose levels were compared at 30,60, 90, and $120 \mathrm{~min}$. The mean blood glucose levels were not significantly different between the two groups (1619.4 $\pm 614.0 \mathrm{mg} / \mathrm{dL}$ (a date) and $1572.0 \pm 967.0 \mathrm{mg} / \mathrm{dL}$ (a sugar cube)) after $2 \mathrm{~h}$ indicating that administration of dates to type 1 diabetic patients [74] is not recommended. Seventeen varieties of Saudi dates were administered to 19 patients with T2DM for evaluation of glycaemic index and load. Shaqra, Sukkary, and Sag'ai date varieties exhibited that the lowest glycaemic index ranging from 42.8 to 44.0 whereas, Ajwa and Shaqra conferred low glycaemic loads (from 8.5 to 9.2) [75]. These date varieties are rich in fructose and fibres, which may be responsible for reducing glycaemic index, glycaemic load, intestinal absorption, and gastric emptying that subsequently reduce the availability of $\alpha$-amylase to its substrate, followed by a reduction in blood glucose level (Figure 1) [76]. Therefore, date varieties with lower glycaemic indices may be incorporated in the diet of diabetic individuals.

Taken together, even though date fruits are high in fructose, its consumption not only regulates plasma glucose concentrations, but also improves $\mathrm{HbA} 1 \mathrm{c}$ and blood glucose levels. Therefore, it is plausible that daily sugary snacks can easily be substituted by date fruits, especially in patients with T2DM. However, due to the few clinical trials examining the effects of date fruits on T2DM patients, it is highly recommended for more trials to be conducted to determine the efficacy, safety as well as the amount of the recommended daily intake required for diabetic patients.

\subsubsection{Antihyperlipidemic Activity}

In a clinical trial, Ali et al. [62] demonstrated that date vinegar can significantly $(p<0.05)$ improve cholesterol and LDL levels while significantly $(p<0.05)$ increasing HDL levels.

\subsubsection{Ameliorating Liver Function}

Interestingly, a clinical trial confirmed that date palm can improve the liver functions in patients with T2DM by improving alkaline phosphatase (ALP) and alanine aminotransferase (ALT) levels without exerting any significant adverse effects [62]. 


\section{Date Fruit Seed}

\subsection{Evidence from In Vivo Studies}

\subsubsection{Antihyperglycemic Activity}

Date seeds are promising source of nutrients, fibres and oil with functional properties $[17,77,78]$. In a 2-week in vivo study [79], date seed significantly reduced blood glucose levels and body weight $(p<0.005)$ of alloxan-induced diabetic rats when compared to control. Besides reduced glucose level, a significant $(p<0.05)$ increase in SOD, CAT, glutathione levels and a significant $(p<0.05)$ decrease in the MDA level were noted in the diabetic rats as compared to the untreated diabetic rats $(444.3 \pm 6.0$ vs. $388.0 \pm 4.5 \mathrm{mg} / \mathrm{dL}$ ) administered with date palm seed extract [76]. Thouri et al. [80] detected in vivo glucose lowering and anti-inflammatory activities of Tunisian date seed which was eventually attributed to the presence of phenolics and flavonoids and antioxidant activities. The seed extracts of two Saudi date varieties (Ajwa and Sukkari) were evaluated in streptozotocin-induced diabetic rats in an eight-week experimental procedure. Following the intervention, blood glucose levels of diabetic rats which received Ajwa date seed extracts were significantly reduced $(434.0 \pm 20.0 \mathrm{mg} / \mathrm{dL}$ vs. $148.0 \pm 28.7 \mathrm{mg} / \mathrm{dL} ; p<0.001)$ as compared to control. This is similarly seen in rats, which received Sukkari date seed extracts as compared to control $(434.0 \pm 20.0 \mathrm{mg} / \mathrm{dL}$ vs. $171.0 \pm 9.2 \mathrm{mg} / \mathrm{dL}$, $p<0.001)$. In addition, the two varieties also reduced diabetic rats' body weight after eight weeks (Ajwa: $279.0 \pm 2.1 \mathrm{~g}$ to $276.0 \pm 7.4 \mathrm{~g}$ and Sukkari: $280.0 \pm 1.0 \mathrm{~g}$ to $275.0 \pm 3.1 \mathrm{~g}$ ), thus, indicating that both varieties can reduce blood glucose levels and therefore have the potential to be investigated as anti-diabetics [81].

Abdelaziz et al. [82] estimated the effect of Phoenix dactylifera date seed in treating early complications of diabetes in streptozotocin-induced diabetic rats. Following the administration of aqueous suspension of date seed for four weeks, glucose level was decreased in date seed-treated rats when compared to untreated rats $(248.0 \pm 42.0 \mathrm{mg} / \mathrm{dL}$ vs. $508.0 \pm 60.0 \mathrm{mg} / \mathrm{dL})$. Khalil et al. [83] demonstrated that blood glucose level was significantly $(p<0.05)$ reduced from baseline $(284.7 \mathrm{mg} / \mathrm{dL}$ vs. $\quad 172.5 \mathrm{mg} / \mathrm{dL}$ ) following a 30-day administration with date seed powder (Zahdi variety) given in combination with fine bran to streptozotocin-induced diabetic rats. Furthermore, date seed supplementation at 5\%,10\%, and 15\% can significantly reduce blood glucose levels in a concentration-dependent manner in male diabetic rats to $176.7 \pm 11.0 \mathrm{mg} / \mathrm{dL}(p<0.05), 130.7 \pm 9.0 \mathrm{mg} / \mathrm{dL}$ $(p<0.01)$ and $121.1 \pm 11.5 \mathrm{mg} / \mathrm{dL}(p<0.001)$, respectively. It is plausible that the date seeds ameliorated glucose levels via its high dietary fibre and high chromium levels, essential for the synthesis of glucose tolerance factors. Date seed may also increase the activity of glucose-6-phosphate dehydrogenase by increasing insulin secretion, thus increasing the influx of glucose into pentose monophosphate shunt and reducing blood glucose levels [84]. In an eight-week in vivo experiment [85], oral administration of date seed extracts along with insulin demonstrated a significant $(p<0.05)$ antihyperglycemic effect on streptozotocin-induced diabetic rats as compared to administration of insulin alone. There was also a significant lowering $(p<0.05)$ of $\mathrm{HbA1c}$ levels due to stimulation of undifferentiated pancreatic islet cells to differentiate into newly formed $\beta$-cells. In fact, other research from a similar group demonstrated that date seed can stimulate endogenous insulin secretion from $\beta$-cell of pancreatic islets in type I diabetic rats [86]. Finally, date seed extract is reported to reduce blood glucose levels in male albino rats $(n=24)$ in a concentration-dependent manner. In the experiment, $10 \%$ and $15 \%$ date seed extracts which were mixed with fortified bread caused significant reduction in glucose levels from $152.5 \pm 3.4 \mathrm{mg} / \mathrm{dL}$ to $119.8 \pm 4.7 \mathrm{mg} / \mathrm{dL}$ (for the former) and to $105.6 \pm 4.1 \mathrm{mg} / \mathrm{dL}$ (for the latter) [87]. It was hypothesized that the effects occur due to the high presence of the dietary fibres which are insoluble in water (including cellulose, hemicellulose and lignin), in addition to micro- and macro elements of date seed [88,89]. 


\subsubsection{Antihyperlipidemic Activity}

Ayatollahi et al. [79] perceived that date seeds have the potential to significantly $(p<0.05)$ reduce LDL and cholesterol levels in diabetic rats as compared to the control group. Abiola et al. [76] and Khalil et al. [83] also detected a significant decrease $(p<0.05)$ in the levels of cholesterol, TG, and LDL with improved levels of HDL in diabetic treated rats as compared to the untreated diabetic rats. Similar results were depicted in other in vivo studies on diabetic rats [87,90]. Hasan et al. [81] detected Saudi date seeds have the potentials to reduce the levels of cholesterol and TG in diabetic rats compared to untreated diabetic rats.

\subsubsection{Against Diabetes-Induced Testicular Toxicity}

Interestingly, in male rats administrated with date seed, testicular antioxidant enzyme status were dramatically improved [90] indicating that date seed has promising effects against diabetic-induced reproductive disorders.

\subsubsection{Ameliorating Liver and Kidney Functions}

In other multiple in vivo studies [79,87], date seeds exhibited the potential to reduce serum levels of creatinine, urea, and ALP in diabetic rats indicating date seeds can ameliorate kidney and liver functions in T2DM. In addition, no acute toxicity was detected even after high dosage of extract administration. Another study [82] also demonstrated that the levels of antioxidant enzymes including glutathione S-transferase, CAT and SOD were also significantly improved in both the kidneys and liver of date seed treated diabetic rats compared to the untreated rats. Subsequently, El Fouhil et al. [91] demonstrated that date seed extract was not only safe, but also minimised the toxic effects in the liver and the kidneys by improving ALT, aspartate aminotransferase, gamma glutamyl transferase, blood urea nitrogen, and creatinine levels.

Taken together, based on the T2DM animal model studies, date seeds are potential anti-diabetic agent due to its glucose and $\mathrm{HbA1c}$ lowering capacities in addition to improving the liver, the kidneys, reproductive system, and overall lipid profile.

\subsection{Evidence from Clinical Studies}

Antihyperglycemic Activity

Gharib et al. [92] evaluated the phenolic content and anti-diabetic effect of date kernels coffee among diabetic patients. Date kernels are a rich source of antioxidants due to the presence of numerous phenolic compounds including epicatechin, ellagic, chlorogenic, gallic, and caffeic acids. In this study, two cups of date kernels coffee in $200 \mathrm{~mL}$ were administered daily for three months (with each cup containing $10 \mathrm{~g}$ date kernels). After three months, fasting glucose to insulin ratio was significantly decreased $(p<0.001)$ with significant improvement in $\beta$-cell function $(p<0.001)$. Therefore, due to the overall improvement of serum glycaemic profile, it was recommended that date kernel has the potentials to be incorporated into an anti-diabetic regimen. However, more clinical studies are required to fully establish this fact.

\section{Date Fruit Leaf}

\subsection{Evidence from In Vivo Studies}

\subsubsection{Antihyperglycemic Activity}

In a recent study conducted on streptozotocin-induced diabetic male Wistar rats [93], when date leaf extract was administered orally, blood glucose, $\mathrm{HbA} 1 \mathrm{c}$ and MDA levels were significantly decreased $(p<0.05)$, while plasma insulin along with a number of $\beta$-cells significantly increased $(p<0.05)$ in treated diabetic rats compared to control rats. Ismail et al. [94] observed after a 28-day follow-up that 
extracts of palm leave tops did not significantly decrease blood glucose levels in streptozotocin-induced diabetic Sprague-Dawley rats (before: $411.1 \pm 84.2 \mathrm{mg} / \mathrm{dL}$ vs. after: $399.7 \pm 172.2 \mathrm{mg} / \mathrm{dL}, p=0.90$ ) as compared to controls. The effect of phenolic compounds extracted from Iraqi date palm leaves were evaluated in alloxan-induced diabetic rabbits $(n=12)$ in a 24-h procedure [95]. When date palm leaf extracts were administered at different intervals, such as 2, 4, 6, and $24 \mathrm{~h}$, blood glucose levels of the diabetic rabbits significantly decreased $(392.3 \pm 4.7 \mathrm{mg} / 100 \mathrm{~mL}$ to $325.5 \pm 4.7 \mathrm{mg} / 100 \mathrm{~mL}$ $(p<0.05), 280.6 \pm 2.7 \mathrm{mg} / 100 \mathrm{~mL}(p<0.01), 238.3 \pm 8.1 \mathrm{mg} / 100 \mathrm{~mL}(p<0.01)$ and $134.5 \pm 4.8 \mathrm{mg} / 100 \mathrm{~mL}$ $(p<0.001)$, respectively). The subsequent reduction indicates that date palm leaf extract has strong glucose-lowering effects in a time-dependent manner. Chakroun et al. [96] reported the presence of ten phenolic compounds in date palm leaf extract and conducted an in vivo study for 28 days in alloxan-induced diabetic mice. They identified that $\alpha$-glucosidase and $\alpha$-amylase enzymes were inhibited by the date palm leaves extract. Significant anti-diabetic activity was observed from date palm leaves extract when compared to Glucor ${ }^{\circledR}$ (acarbose) administered at $50 \mathrm{mg} / \mathrm{kg}$. This finding confirms that date palm leaf extract can reduce blood glucose levels and may have superior anti-diabetic effect as compared to Glucor ${ }^{\circledR}$.

Following the administration of Ziziphus jujube (jujube date) leaf extract in alloxan-induced diabetic rats, there were significant $(p<0.001$ ) reduction in blood glucose levels (from $767.8 \mathrm{mg} / \mathrm{dL}$ to $250.9 \mathrm{mg} / \mathrm{dL}$ ) although when compared with glibenclamide-administrated group, the difference was not significant as reported by Eddine et al. [13]. The mechanism behind this discovery could be hypothesised as due to the contribution of jujube date in stimulating $\beta$-cells and activating insulin receptors and subsequently lowering the blood glucose level [97]. In an interesting study [98], upon subacute administration of Phoenix dactylifera leaf extract in alloxan-induced male Wister rats, blood glucose and insulin levels significantly improved. Similar results were confirmed by Abuelgassim et al. [99] where date palm leaf extract was incorporated in alloxan-induced male Wister diabetic rats. Subsequently after 4 weeks, there was a significant glucose reduction in diabetic rats $(17.43 \pm 0.76$ to $16.77 \pm 0.28 \mathrm{mmol} / \mathrm{L} /)$ as compared to controls. It is hypothesised that the leave extract promotes insulin secretion by closing the $\mathrm{K}^{+}$ATP channels. Additionally, some components of leaves extract such as flavonoids, phenols, steroids and saponins have free radical scavenging abilities. It may also reduce water intake and improve body weight with a reverse dyslipidaemia effect $[100,101]$.

\subsubsection{Antihyperlipidemic Activity}

In an in vivo study, Mard et al. [98] demonstrated that upon administration of subacute Phoenix dactylifera leaf extract, both cholesterol and TG levels improved in diabetic male Wister rats compared to the control group. Abuelgassim et al. [99] also confirmed that administration of date palm leaf can significantly improve cholesterol $(p<0.001)$ and LDL levels $(p<0.001)$, however, no significant improvement on serum HDL levels.

\subsubsection{Ameliorating Haematological Parameters}

Nuha et al. [95] reported from an in vivo study that the phenolic compounds identified in date leaves possessed no toxic effects on red blood cells.

Therefore, these results suggest that date leaves have potential roles in lowering plasma glucose, $\mathrm{HbA1c}$, regulating lipid profile, protecting haematological parameters and, subsequently, improving diabetes and diabetes-associated complications in animal models.

\section{Conclusions}

Firstly, based on the in vivo and human studies, dates do not increase glucose levels, and glycaemic index in T2DM, rather, ameliorates diabetes-induced complications. Secondly, dates have the potential to lower glucose levels contributed by the polyphenols, flavonoids, and antioxidants. The possible mechanisms of actions were (i) stimulation of $\beta$-cell, (ii) increase in the number of islets and $\beta$-cells, (iii) decrease $\beta$-cell apoptosis and delay carbohydrate breakdown by inhibiting $\alpha$-amylase, 
(iv) enhancement of $\alpha$-glucosidase enzyme activities, and (v) reduce intestinal glucose absorption. Therefore, date glucose lowering activities should be explored further in larger studies and clinical trials for confirmation of its efficacy and safety in diabetic patients.

Author Contributions: Conceptualization, M.A.I. and S.H.G.; methodology, M.A.I.; resources, M.A.I. and S.H.G.; writing-original draft preparation, M.A.-T.M. and M.G.M.; writing-review and editing, M.A.I., S.H.G., and M.I.K.; supervision, M.A.I.; project administration, M.A.I. All authors have read and agreed to the published version of the manuscript.

Funding: This research received no external funding.

Conflicts of Interest: The authors declare no conflict of interest.

\section{References}

1. Islam, M.A.; Alam, F.; Solayman, M.; Khalil, M.I.; Kamal, M.A.; Gan, S.H. Dietary phytochemicals: Natural swords combating inflammation and oxidation-mediated degenerative diseases. Oxid. Med. Cell. Longev. 2016, 2016, 1-25. [CrossRef]

2. Solayman, M.; Ali, Y.; Alam, F.; Islam, M.A.; Alam, N.; Khalil, M.I.; Gan, S.H. Polyphenols: Potential future arsenals in the treatment of diabetes. Curr. Pharm. Des. 2016, 22, 549-565. [CrossRef] [PubMed]

3. Alam, F.; Islam, M.A.; Mohamed, M.; Ahmad, I.; Kamal, M.A.; Donnelly, R.; Idris, I.; Gan, S.H. Efficacy and safety of pioglitazone monotherapy in type 2 diabetes mellitus: A systematic review and meta-analysis of randomised controlled trials. Sci. Rep. 2019, 9, 1-13. [CrossRef] [PubMed]

4. Alam, F.; Islam, M.A.; Kamal, M.A.; Gan, S.H. Updates on managing type 2 diabetes mellitus with natural products: Towards antidiabetic drug development. Curr. Med. Chem. 2018, 25, 5395-5431. [CrossRef] [PubMed]

5. Cory, H.; Passarelli, S.; Szeto, J.; Tamez, M.; Mattei, J. The role of polyphenols in human health and food systems: A mini-review. Front. Nutr. 2018, 5, 1-9. [CrossRef] [PubMed]

6. Souli, I.; Jemni, M.; Rodríguez-Verástegui, L.L.; Chaira, N.; Artés, F.; Ferchichi, A. Phenolic composition profiling of Tunisian 10 varieties of common dates (Phoenix dactylifera L.) at tamar stage using LC-ESI-MS and antioxidant activity. J. Food Biochem. 2018, 42, e12634. [CrossRef]

7. Hussain, M.I.; Farooq, M.; Syed, Q.A. Nutritional and biological characteristics of the date palm fruit (Phoenix dactylifera L.)-A review. Food Biosci. 2020, 34, 100509. [CrossRef]

8. Al-Farsi, M.A.; Lee, C.Y. Nutritional and functional properties of dates: A review. Crit. Rev. Food Sci. Nutr. 2008, 48, 877-887. [CrossRef]

9. Dayang, J.; Reuben, C.; Raji, F. Nutritional, socioeconomic and health benefits of dates. Int. J. Food Nutr. Sci. 2014, 3, 63-73.

10. El Abed, H.; Chakroun, M.; Fendri, I.; Makni, M.; Bouaziz, M.; Drira, N.; Mejdoub, H.; Khemakhem, B. Extraction optimization and in vitro and in vivo anti-postprandial hyperglycemia effects of inhibitor from Phoenix dactylifera L. parthenocarpic fruit. Biomed. Pharmacother. 2017, 88, 835-843. [CrossRef]

11. Farag, M.A.; Porzel, A.; Wessjohann, L.A. Unraveling the active hypoglycemic agent trigonelline in Balanites aegyptiaca date fruit using metabolite fingerprinting by NMR. J. Pharm. Biomed. Anal. 2015, 115, 383-387. [CrossRef]

12. Al-Zuhair, S.; Dowaidar, A.; Kamal, H. Inhibitory effect of dates-extract on $\alpha$-Amylase and $\beta$-glucosidase enzymes relevant to non-insulin dependent diabetes mellitus. J. Biochem. Technol. 2010, 2, 158-160.

13. Eddine, L.S.; Segni, L.; Noureddine, G.; Redha, O.M.; Sonia, M. Scavenging Effect, Anti-Inflammatory and Diabetes Related Enzyme Inhibition Properties of Leaves Extract from Selected Varieties of Phoenix dactylifera L. Int. J. Pharmacogn. Phytochem. Res. 2014, 6, 66-73.

14. Chaudhary, S.; Pankaj, A. Dates and Diabetes J. Soc. Health Diabetes. 2018, 6, 109-110. [CrossRef]

15. Alkaabi, J.M.; Al-Dabbagh, B.; Ahmad, S.; Saadi, H.F.; Gariballa, S.; Al Ghazali, M. Glycemic indices of five varieties of dates in healthy and diabetic subjects. Nutr. J. 2011, 10, 1-9. [CrossRef]

16. Mrabet, A.; Hammadi, H.; Rodríguez-Gutiérrez, G.; Jiménez-Araujo, A.; Sindic, M. Date Palm Fruits as a Potential Source of Functional Dietary Fiber: A Review. Food Sci. Technol. Res. 2019, 25, 1-10. [CrossRef]

17. Mrabet, A.; Jiménez-Araujo, A.; Guillén-Bejarano, R.; Rodríguez-Arcos, R.; Sindic, M. Date Seeds: A Promising Source of Oil with Functional Properties. Foods 2020, 9, 787. 
18. Alqarni, M.M.; Osman, M.A.; Al-Tamimi, D.S.; Gassem, M.A.; Al-Khalifa, A.S.; Al-Juhaimi, F.; Mohamed Ahmed, I.A. Antioxidant and antihyperlipidemic effects of Ajwa date (Phoenix dactylifera L.) extracts in rats fed a cholesterol-rich diet. J. Food Biochem. 2019, 43, e12933. [CrossRef]

19. Khan, F.; Khan, T.J.; Kalamegam, G.; Pushparaj, P.N.; Chaudhary, A.; Abuzenadah, A.; Kumosani, T.; Barbour, E.; Al-Qahtani, M. Anti-cancer effects of Ajwa dates (Phoenix dactylifera L.) in diethylnitrosamine induced hepatocellular carcinoma in Wistar rats. BMC Complement. Altern. Med. 2017, 17, 418. [CrossRef]

20. Maqsood, S.; Adiamo, O.; Ahmad, M.; Mudgil, P. Bioactive compounds from date fruit and seed as potential nutraceutical and functional food ingredients. Food Chem. 2020, 308, 125522. [CrossRef]

21. Saryono, S. Date Seeds Drinking as Antidiabetic: A Systematic Review. In Proceedings of the IOP Conference Series: Earth and Environmental Science, Purwokerto, Central Java, Indonesia, 14-16 November 2018; p. 012018.

22. Taha, R.; Ben Maachia, S.; Sindic, M.; Sahli, A.; Namsi, A.; Messaoud, M. Chemical fruit composition of Tunisian date palm 'Deglet Nour' collected at maturation from four different oases in Djerid region. J. Food Technol. 2019, 17, 1-10.

23. Siddeeg, A.; Zeng, X.-A.; Ammar, A.-F.; Han, Z. Sugar profile, volatile compounds, composition and antioxidant activity of Sukkari date palm fruit. J. Food Sci. Technol. 2019, 56, 754-762. [CrossRef] [PubMed]

24. Nehdi, I.; Omri, S.; Khalil, M.; Al-Resayes, S. Characteristics and chemical composition of date palm (Phoenix canariensis) seeds and seed oil. Ind. Crop. Prod. 2010, 32, 360-365. [CrossRef]

25. Bentrad, N.; Gaceb-Terrak, R.; Benmalek, Y.; Rahmania, F. Studies on chemical composition and antimicrobial activities of bioactive molecules from date palm (Phoenix dactylifera L.) pollens and seeds. Afr. J. Tradit. Complement. Altern. Med. 2017, 14, 242-256. [CrossRef]

26. Atghaei, M.; Sefidkon, F.; Darini, A.; Sadeghzadeh Hemayati, S.; Abdossi, V. Essential Oil Content and Composition of the Spathe in Some Date Palm (Phoenix dactylifera L.) Varieties in Iran. J. Essent. Oil Bear. Plants 2020, 23, 292-300. [CrossRef]

27. Hammouda, H.d.; Chérif, J.K.; Trabelsi-Ayadi, M.; Baron, A.; Guyot, S. Detailed polyphenol and tannin composition and its variability in Tunisian dates (Phoenix dactylifera L.) at different maturity stages. J. Agric. Food Chem. 2013, 61, 3252-3263. [CrossRef]

28. Chaira, N.; Smaali, M.I.; Martinez-Tomé, M.; Mrabet, A.; Murcia, M.A.; Ferchichi, A. Simple phenolic composition, flavonoid contents and antioxidant capacities in water-methanol extracts of Tunisian common date cultivars (Phoenix dactylifera L.). Int. J. Food Sci. Nutr. 2009, 60, 316-329. [CrossRef]

29. Abbas, F.A.; Ateya, A.-M. Estradiol, esteriol, estrone and novel flavonoids from date palm pollen. Aust. J. Basic Appl. Sci. 2011, 5, 606-614.

30. Suresh, S.; Guizani, N.; Al-Ruzeiki, M.; Al-Hadhrami, A.; Al-Dohani, H.; Al-Kindi, I.; Rahman, M.S. Thermal characteristics, chemical composition and polyphenol contents of date-pits powder. J. Food Eng. 2013, 119, 668-679. [CrossRef]

31. Singh, V.; Guizani, N.; Essa, M.; Hakkim, F.; Rahman, M. Comparative analysis of total phenolics, flavonoid content and antioxidant profile of different date varieties (Phoenix dactylifera L.) from Sultanate of Oman. Int. Food Res. J. 2012, 19, 1063.

32. Eid, N.M.; Al-Awadi, B.; Vauzour, D.; Oruna-Concha, M.J.; Spencer, J.P. Effect of cultivar type and ripening on the polyphenol content of date palm fruit. J. Agric. Food Chem. 2013, 61, 2453-2460. [CrossRef]

33. El Modafar, C.; El Boustani, E. Cell wall-bound phenolic acid and lignin contents in date palm as related to its resistance to Fusarium oxysporum. Biol. Plant. 2001, 44, 125-130. [CrossRef]

34. Daoud, A.; Malika, D.; Bakari, S.; Hfaiedh, N.; Mnafgui, K.; Kadri, A.; Gharsallah, N. Assessment of polyphenol composition, antioxidant and antimicrobial properties of various extracts of Date Palm Pollen (DPP) from two Tunisian cultivars. Arab. J. Chem. 2015, 12, 3075-3086. [CrossRef]

35. Fang, F.; Li, J.-M.; Zhang, P.; Tang, K.; Wang, W.; Pan, Q.-H.; Huang, W.-D. Effects of grape variety, harvest date, fermentation vessel and wine ageing on flavonoid concentration in red wines. Food Res. Int. 2008, 41, 53-60. [CrossRef]

36. Michael, H.N.; Salib, J.Y.; Eskander, E.F. Bioactivity of diosmetin glycosides isolated from the epicarp of date fruits, Phoenix dactylifera, on the biochemical profile of alloxan diabetic male rats. Phytother. Res. 2013, 27, 699-704. [CrossRef] [PubMed]

37. Hussein, A.M.; El-Mousalamy, A.M.; Hussein, S.A.; Mahmoud, S.A. Effects of palm dates (Phoenix dactylifera L.) extracts on hepatic dysfunctions in Type 2 diabetic rat model. World J. Pharm. Pharm. Sci. 2015, 4, 62-79. 
38. Al-Malki, A.L.; Barbour, E.K.; Abulnaja, K.O.; Moselhy, S.S. Management of hyperglycaemia by ethyl acetate extract of Balanites aegyptiaca (desert date). Molecules 2015, 20, 14425-14434. [CrossRef]

39. Al-Alawi, R.A.; Al-Mashiqri, J.H.; Al-Nadabi, J.S.; Al-Shihi, B.I.; Baqi, Y. Date palm tree (Phoenix dactylifera L.): Natural products and therapeutic options. Front. Plant Sci. 2017, 8, 845. [CrossRef]

40. Regnault-Roger, C.; Hadidane, R.; Biard, J.-F.; Boukef, K. High performance liquid and thin-layer chromatographic determination of phenolic acids in palm (Phoenix dactilifera) products. Food Chem. 1987, 25, 61-71. [CrossRef]

41. Taleb, H.; Morris, R.K.; Withycombe, C.E.; Maddocks, S.E.; Kanekanian, A.D. Date syrup-derived polyphenols attenuate angiogenic responses and exhibits anti-inflammatory activity mediated by vascular endothelial growth factor and cyclooxygenase-2 expression in endothelial cells. Nutr. Res. 2016, 36, 636-647. [CrossRef]

42. Ammar, N.M.; Lamia, T.; Abou, E.; Nabil, H.; Lalita, M.; Tom, J. Flavonoid Constituents and Antimicrobial Activity of Date (Phoenix dactylifera L.) Seeds Growing in Egypt. Biology 2009, 3, 1-5.

43. Sachde, A.G.; Al-Bakir, A.Y.; Abdul-Raheem, J.A. Polyphenol oxidase from Barhee and Zahdi dates. II. Characterization. J. Food Biochem. 1988, 12, 241-252. [CrossRef]

44. Sirisena, S.; Zabaras, D.; Ng, K.; Ajlouni, S. Characterization of Date (Deglet Nour) Seed Free and Bound Polyphenols by High-Performance Liquid Chromatography-Mass Spectrometry. J. Food Sci. 2017, 82, 333-340. [CrossRef]

45. Sirisena, S.; Ajlouni, S.; Ng, K. Simulated gastrointestinal digestion and in vitro colonic fermentation of date (Phoenix dactylifera L.) seed polyphenols. Int. J. Food Sci. Technol. 2018, 53, 412-422. [CrossRef]

46. Saddi, A.A.; Mohamed, A.M.; Shaikh, A.M. Prophylactic mechanisms of Cucumis melo var. flexuosus and Phoenix dactylifera fruit extracts against diabetic cardiomyopathy in streptozotocin induced diabetic rats. Pak. J. Pharm. Sci. 2018, 31, 699-707. [PubMed]

47. Zaakouk, S.; el-Rasheid, A.; Hesham, G.; Belal, A.; Elfeky, K. Effect of Balanites aegyptiaca (heglig dates) and persea americana (avocado fruit) on some hematological and biochemical parameters in streptozotocin induced diabetic male rats. Al-Azhar Bull. Sci. 2018, 29, 49-59.

48. Alam, F.; Islam, M.A.; Khalil, M.I.; Gan, S.H. Metabolic control of type 2 diabetes by targeting the GLUT4 glucose transporter: Intervention approaches. Curr. Pharm. Des. 2016, 22, 3034-3049. [CrossRef]

49. Victor, A.C. Ethanol pulp extract of date palm (Phoenix dactylifera) modulates hematinic indices in diabetic rats. Ann. Food Sci. Technol. 2017, 15, 297-306.

50. Evans, G.H.; McLaughlin, J.; Yau, A.M. The Effect of Glucose or Fructose Added to a Semi-solid Meal on Gastric Emptying Rate, Appetite, and Blood Biochemistry. Front. Nutr. 2018, 5, 1-7. [CrossRef]

51. Ahmed, S.; Khan, R.A.; Jamil, S.; Afroz, S. Antidiabetic effects of native date fruit Aseel (Phoenix dactylifera L.) in normal and hyperglycemic rats. Pak. J. Pharm. Sci. 2017, 30, 1797-1802.

52. Sekhon-Loodu, S.; Rupasinghe, H. Evaluation of antioxidant, antidiabetic and antiobesity potential of selected traditional medicinal plants. Front. Nutr. 2019, 6, 1-11. [CrossRef] [PubMed]

53. Ibrahim, M.O.; Ahmad, M.N.; Hamad, H.J.; Hamad, W.J. Effect of Birhi Variety of Date Palm Fruits, (Phoenix dactylifera L.) at the Tamr Stage on Serum Glucose Levels in Streptozotocin-Induced Diabetic Rats. J. Agric. Sci. 2016, 8, 110-118.

54. Abou Khalil, N.S.; Abou-Elhamd, A.S.; Wasfy, S.I.; El Mileegy, I.M.; Hamed, M.Y.; Ageely, H.M. Antidiabetic and antioxidant impacts of desert date (Balanites aegyptiaca) and parsley (Petroselinum sativum) aqueous extracts: Lessons from experimental rats. J. Diabetes Res. 2016, 2016, 1-10. [CrossRef]

55. Kim, E.-K.; Kwon, K.-B.; Song, M.-Y.; Seo, S.-W.; Park, S.-J.; Ka, S.-O.; Na, L.; Kim, K.-A.; Ryu, D.-G.; So, H.-S. Genistein protects pancreatic $\beta$ cells against cytokine-mediated toxicity. Mol. Cell. Endocrinol. 2007, 278, 18-28. [CrossRef]

56. Bendary, M.; Zawawi, B.M. A study on the possible role of date fruit on the electrophysiology and neuropathic changes in diabetic polyneuropathy. J. Biosci. Appl. Res. 2016, 2, 524-531. [CrossRef]

57. Olawole, T.D.; Okundigie, M.I.; Rotimi, S.O.; Okwumabua, O.; Afolabi, I.S. Preadministration of fermented sorghum diet provides protection against hyperglycemia-induced oxidative stress and suppressed glucose utilization in alloxan-induced diabetic rats. Front. Nutr. 2018, 5, 1-8. [CrossRef]

58. Amouoghli, T.B.; Hassanpour, A.; Kohi, V.; Ostovar, A.; Alizadeh, A. The effects of date consumption on serumic levels of glucose, lipids and lipoproteins in diabetic rats. Vet. Clin. Pathol. 2009, 3, 367-375. 
59. Hosseinipour, M.; Goodarzi, N.; Bakhtiari, M. Protective efficiency of Ashrasi date palm hydroalcoholic extract against diabetes-induced testicular toxicity: A biochemical and stereological study. Andrologia 2019, 51, 1-12. [CrossRef] [PubMed]

60. Zangiabadi, N.; Asadi-Shekaari, M.; Sheibani, V.; Jafari, M.; Shabani, M.; Asadi, A.R.; Tajadini, H.; Jarahi, M. Date fruit extract is a neuroprotective agent in diabetic peripheral neuropathy in streptozotocin-induced diabetic rats: A multimodal analysis. Oxid. Med. Cell. Longev. 2011, 2011, 1-9. [CrossRef]

61. Chung, A.P.; Gurtu, S.; Chakravarthi, S.; Moorthy, M.; Palanisamy, U.D. Geraniin protects high-fat diet-induced oxidative stress in Sprague Dawley Rats. Front. Nutr. 2018, 5, 1-8. [CrossRef]

62. Ali, Z.; Ma, H.; Wali, A.; Ayim, I.; Rashid, M.T.; Younas, S. A double-blinded, randomized, placebo-controlled study evaluating the impact of dates vinegar consumption on blood biochemical and hematological parameters in patients with type 2 diabetes. Trop. J. Pharm. Res. 2018, 17, 2463-2469. [CrossRef]

63. Fushimi, T.; Tayama, K.; Fukaya, M.; Kitakoshi, K.; Nakai, N.; Tsukamoto, Y.; Sato, Y. The efficacy of acetic acid for glycogen repletion in rat skeletal muscle after exercise. Int. J. Sports Med. 2002, 23, 218-222. [CrossRef] [PubMed]

64. Hlebowicz, J.; Darwiche, G.; Björgell, O.; Almér, L.-O. Effect of apple cider vinegar on delayed gastric emptying in patients with type 1 diabetes mellitus: A pilot study. BMC Gastroenterol. 2007, 7, 46. [CrossRef] [PubMed]

65. Al-Mssallem, M. Consumption of Dates among Saudi Adults and its Association with the Prevalence of Type 2 Diabetes. Asian J. Clin. Nutr. 2018, 10, 58-64. [CrossRef]

66. Hossain, A.S. Dried Dates Fruit and its Biochemical and Nutrient Content: Uses as Diabetic Food. Asian J. Clin. Nutr. 2015, 7, 90-95. [CrossRef]

67. Williamson, G.; Carughi, A. Polyphenol content and health benefits of raisins. Nutr. Res. 2010, 30, 511-519. [CrossRef]

68. Foshati, S.; Nouripour, F.; Akhlaghi, M. Effect of Date and Raisin Snacks on Glucose Response in Type 2 Diabetes. Nutr. Food Sci. Res. 2015, 2, 19-25.

69. Alkaabi, J.; Al-Dabbagh, B.; Saadi, H.; Gariballa, S.; Yasin, J. Effect of traditional Arabic coffee consumption on the glycemic index of Khalas dates tested in healthy and diabetic subjects. Asia Pac. J. Clin. Nutr. 2013, 22, 565-572.

70. Forghani, B.; Kasaeian, N.; Tala, M.M.; Zare, M.; Haghighi, S.; Amini, A. Effect of dates (khorma) on 2hour postprandial (2hpp) blood glucose level in type 2 diabetic patients reterred to isfahan endocrine and metabolism research center. J. Shahid Sadoughi Univ. Med. Sci. Health Serv. 2003, 10, 52-55.

71. Avogaro, A.; Toffolo, G.; Valerio, A.; Cobelli, C. Epinephrine exerts opposite effects on peripheral glucose disposal and glucose-stimulated insulin secretion: A stable label intravenous glucose tolerance test minimal model study. Diabetes 1996, 45, 1373-1378. [CrossRef]

72. Ahmed, M.; Al-Othaimeen, A.; De Vol, E.; Bold, A. Comparative responses of plasma glucose, insulin and C-peptide following ingestion of isocaloric glucose, a modified urban Saudi breakfast and dates in normal Saudi persons. Ann. Saudi Med. 1991, 11, 414-417. [CrossRef] [PubMed]

73. Aldughpassi, A.; Wolever, T.M. Effect of coffee and tea on the glycaemic index of foods: No effect on mean but reduced variability. Br. J. Nutr. 2009, 101, 1282-1285. [CrossRef] [PubMed]

74. Razaghi-azar, M.; Noori, N.; Afsharian, K. Effect of date on blood sugar in patients with type 1 diabetes mellitus. Iran. J. Diabetes Metab. 2005, 4, 27-34.

75. AlGeffari, M.A.; Almogbel, E.S.; Alhomaidan, H.T.; El-Mergawi, R.; Barrimah, I.A. Glycemic indices, glycemic load and glycemic response for seventeen varieties of dates grown in Saudi Arabia. Ann. Saudi Med. 2016, 36, 397-403. [CrossRef]

76. Abiola, T.; Dibie, D.; Akinwale, O.; Shomuyiwa, O. Assessment of the Antidiabetic Potential of the Ethanolic Extract of Date Palm (Phoenix Dactylifera) Seed in Alloxan-Induced Diabetic Rats. J. Diabetes Metab. 2018, 9 , 1-9.

77. Bouaziz, F.; Ben Abdeddayem, A.; Koubaa, M.; Ellouz Ghorbel, R.; Ellouz Chaabouni, S. Date Seeds as a Natural Source of Dietary Fibers to Improve Texture and Sensory Properties of Wheat Bread. Foods 2020, 9, 737. [CrossRef]

78. Turki, M.; Barbosa-Pereira, L.; Bertolino, M.; Essaidi, I.; Ghirardello, D.; Torri, L.; Bouzouita, N.; Zeppa, G. Physico-Chemical Characterization of Tunisian Canary Palm (Phoenix canariensis Hort. Ex Chabaud) Dates and Evaluation of Their Addition in Biscuits. Foods 2020, 9, 695. [CrossRef] 
79. Ayatollahi, S.A.; Sharifi-Rad, M.; Roointan, A.; Baghalpour, N.; Salehi, B.; Shinwari, Z.K.; Khalil, A.T.; Sharifi-Rad, J. Antidiabetic Activity of Date Seed Methanolic Extracts in Alloxan-Induced Diabetic Rats. Pak. Vet. J. 2019, 39, 583-587. [CrossRef]

80. Thouri, A.; Chahdoura, H.; El Arem, A.; Hichri, A.O.; Hassin, R.B.; Achour, L. Effect of solvents extraction on phytochemical components and biological activities of Tunisian date seeds (var. Korkobbi and Arechti). Bmc Complement. Altern. Med. 2017, 17, 1-10. [CrossRef]

81. Hasan, M.; Mohieldein, A. In vivo evaluation of anti diabetic, hypolipidemic, antioxidative activities of Saudi date seed extract on streptozotocin induced diabetic rats. J. Clin. Diagn. Res. 2016, 10, 1-12. [CrossRef]

82. Abdelaziz, D.H.; Ali, S.A.; Mostafa, M.M. Phoenix dactylifera seeds ameliorate early diabetic complications in streptozotocin-induced diabetic rats. Pharm. Biol. 2015, 53, 792-799. [CrossRef]

83. Khalil, M.M.; Abou-Raya, M.; Ghoniem, G.A.; Hussain, T. Effect of feeding at different levels of wheat bran and date seeds powder on diabetic rats. J. Food Dairy Sci. 2015, 6, 435-449. [CrossRef]

84. Olagunju, J.; Jobi, A.; Oyedapo, O. An investigation into the biochemical basis of the observed hyperglycaemia in rats treated with ethanol root extract of Plumbago zeylanica. Phytother. Res. 1999, 13, 346-348. [CrossRef]

85. El Fouhil, A.F.; Ahmed, A.M.; Darwish, H.H. Hypoglycemic effect of an extract from date seeds on diabetic rats. Saudi Med. J. 2010, 31, 747-751.

86. El Fouhil, A.F.; Ahmed, A.M.; Atteya, M.; Mohamed, R.A.; Moustafa, A.S.; Al-Roalle, A.H.; Darwish, H.H. Hypoglycemic effects of date seed extract. Possible mechanism of action, and potential therapeutic implications. Saudi Med. J. 2013, 34, 1125-1132. [PubMed]

87. Halaby, M.S.; Farag, M.H.; Gerges, A.H. Potential effect of date pits fortified bread on diabetic rats. Int. J. Nutr. Food Sci. 2014, 3, 49-59. [CrossRef]

88. Ardekani, M.R.S.; Khanavi, M.; Hajimahmoodi, M.; Jahangiri, M.; Hadjiakhoondi, A. Comparison of antioxidant activity and total phenol contents of some date seed varieties from Iran. Iran. J. Pharm. Res. 2010, $9,141$.

89. Amany, M.; Shaker, M.; Abeer, A. Antioxidant activities of date pits in a model meat system. Int. Food Res. J. 2012, 19, 223-227.

90. Abdallaha, I.Z.; Khattab, H.A.; Ragheb, E.M.; Yousef, F.M.; Alkreathy, H.M. Date Pits Alleviate Reproductive Disorders in Male Diabetic Rats. Glob. J. Pharmacol. 2015, 9, 208-221.

91. El Fouhil, A.F.; Ahmed, A.M.; Darwish, H.H.; Atteya, M.; Al-Roalle, A.H. An extract from date seeds having a hypoglycemic effect. Is It Safe to Use? Saudi Med. J. 2011, 32, 791-796.

92. Gharib, M.A.A.-K.; Bakrand, E.-S.H.; Baz, S.M. Hypoglycemic Efficacy of Date Kernels Coffee on Diabetic and Nephrodiabetic Patients. Life Sci. J. 2016, 13, 10-18.

93. Esfandiari, E.; Dorali, A.; Ghanadian, M.; Rashidi, B.; Mostafavi, F.S. Protective and therapeutic effects of Phoenix dactylifera leaf extract on pancreatic $\beta$-cells and diabetic parameters in streptozotocin-induced diabetic rats. Comp. Clin. Path. 2020. [CrossRef]

94. Mohamed, S.; Abuzaid, O.I.; El-Ashmawy, I.M. Effect of aqueous extract of tops of date palm leaves on blood glucose of diabetic rats. Pak. J. Pharm. Sci. 2017, 30, 2031-2037.

95. Nuha, A.D.M.A.-M.; Al-Obaid, A.M. Hypoglycemic Action of Synergistic Interaction of Phenolic Compounds Isolated from Iraqi Phoenix dactylifera (Breim) Leaflets in Alloxan-Induced Diabetic Rabbits. J. Nat. Sci. Res. 2016, 6, 22-31.

96. Chakroun, M.; Khemakhem, B.; Mabrouk, H.B.; El Abed, H.; Makni, M.; Bouaziz, M.; Drira, N.; Marrakchi, N.; Mejdoub, H. Evaluation of anti-diabetic and anti-tumoral activities of bioactive compounds from Phoenix dactylifera L's leaf: In vitro and in vivo approach. Biomed. Pharmacother. 2016, 84, 415-422. [CrossRef]

97. Shirdel, Z.; Mirbadalzadeh, R. Improvement of hyperglycemia in diabetic rats by Ethanolic extract of red date leaves. Hor. Sig. 2011, 31, 1957-1959.

98. Mard, S.A.; Jalalvand, K.; Jafarinejad, M.; Balochi, H.; Naseri, M.K.G. Evaluation of the antidiabetic and antilipaemic activities of the hydroalcoholic extract of Phoenix dactylifera palm leaves and its fractions in alloxan-induced diabetic rats. Malays. J. Med. Sci. 2010, 17, 4-13.

99. Abuelgassim, A.O. Effect of flax seeds and date palm leaves extracts on serum concentrations of glucose and lipids in alloxan diabetic rats. Pak. J. Biol. Sci. 2010, 13, 1141-1145. 
100. Venkateswaran, S.; Pari, L. Effect of Coccinia indica on blood glucose, insulin and key hepatic enzymes in experimental diabetes. Pharm. Biol. 2002, 40, 165-170. [CrossRef]

101. Jurgoński, A.; Juśkiewicz, J.; Zduńczyk, Z. Ingestion of black chokeberry fruit extract leads to intestinal and systemic changes in a rat model of prediabetes and hyperlipidemia. Plant Foods Hum. Nutr. 2008, 63, 176-182. [CrossRef]

Publisher's Note: MDPI stays neutral with regard to jurisdictional claims in published maps and institutional affiliations.

(C) 2020 by the authors. Licensee MDPI, Basel, Switzerland. This article is an open access article distributed under the terms and conditions of the Creative Commons Attribution (CC BY) license (http://creativecommons.org/licenses/by/4.0/). 